\title{
AUTHORS' CORRECTIONS
}

\section{NAD-Glycohydrolase Production and spe $A$ and speC Distribution in Group A Streptococcus (GAS) Isolates Do Not Correlate with Severe GAS Diseases in the Australian Population}

\author{
Armando DelVecchio, Michael Maley, Bart J. Currie, and K. S. Sriprakash \\ Menzies School of Health Research and Co-operative Research Centre for Aboriginal and Tropical Health, \\ Darwin, Queensland Institute of Medical Research, Brisbane, and South Western \\ Area Pathology Services, Liverpool, Sydney, Australia
}

Volume 40, no. 7, p. 2642-2644, 2002. Page 2643, column 1: The first sentence of the second full paragraph should be deleted and replaced with the following text. "The NADase activity in culture supernatants was measured as described by Lutticken et al. (15a), with a few modifications (see below). Overnight cultures of GAS were clarified by centrifugation at $2,000 \times g$ for 10 min."

Page 2644: The following reference was inadvertently omitted.

15a. Lütticken, R., D. Lütticken, D. R. Johnson, and L. W. Wannamaker. 1976. Application of a new method for detecting streptococcal nicotinamide adenine dinucleotide glycohydrolase to various $\mathrm{M}$ types of Streptococcus pyogenes. J. Clin. Microbiol. 3:533-536.

\section{Detection of Smallpox Virus DNA by LightCycler PCR}

Mark J. Espy, Franklin R. Cockerill III, Richard F. Meyer, Michael D. Bowen, Gregory A. Poland, Ted L. Hadfield, and Thomas F. Smith

Division of Clinical Microbiology, Division of Infectious Diseases, and Division of General Internal Medicine, Mayo Clinic and Foundation, Rochester, Minnesota; Centers for Disease Control and Prevention, Atlanta, Georgia; and Armed Forces Institute of Pathology, Walter Reed Army Medical Center, Washington, D.C.

Volume 40, no. 6, p. 1985-1988, 2002. Page 1985: The nucleic acid sequences of the primer that was used to amplify the smallpox virus hemagglutinin gene target (GenBank accession no. M14783) and of the probe that was used in the assay are as follows: for the primer, 5'-CTA ATA TCA TTA GTA TAC GCT ACA C-3' (sense) and 5'-GAG TCG TAA GAT ATT TTA TCC-3' (antisense), and for the probe, 5'-AAT GAT TAT GTT GTT ATG AGT GCT TG-fluorescein-3' and 5'-RED 640-TAT AAG GAG CCC AAT TCC ATT ATT CT-PHOS-3'. 